Article

\title{
Investigation of the Antibacterial Activity and Efflux Pump Inhibitory Effect of Cycas thouarsii R.Br. Extract against Klebsiella pneumoniae Clinical Isolates
}

\author{
Walaa A. Negm ${ }^{1, *(1)}$, Mona El-Aasr ${ }^{1}\left(\mathbb{D}\right.$, Amal Abo Kamer ${ }^{2}$ and Engy Elekhnawy ${ }^{2, *(1)}$ \\ 1 Pharmacognosy Department, Faculty of Pharmacy, Tanta University, Tanta 31111, Egypt; \\ moelaasar@pharm.tanta.edu.eg \\ 2 Pharmaceutical Microbiology Department, Faculty of Pharmacy, Tanta University, Tanta 31111, Egypt; \\ amalabokamer@pharm.tanta.edu.eg \\ * Correspondence: walaa.negm@pharm.tanta.edu.eg (W.A.N.); engy.ali@pharm.tanta.edu.eg (E.E.)
}

check for updates

Citation: Negm, W.A.; El-Aasr, M.; Kamer, A.A.; Elekhnawy, E. Investigation of the Antibacterial Activity and Efflux Pump Inhibitory Effect of Cycas thouarsii R.Br. Extract against Klebsiella pneumoniae Clinical Isolates. Pharmaceuticals 2021, 14, 756. https://doi.org/10.3390/ph14080756

Academic Editors: Eduarda M. P. Silva and Diana Cláudia Pinto

Received: 3 July 2021

Accepted: 23 July 2021

Published: 1 August 2021

Publisher's Note: MDPI stays neutral with regard to jurisdictional claims in published maps and institutional affiliations.

Copyright: (c) 2021 by the authors. Licensee MDPI, Basel, Switzerland. This article is an open access article distributed under the terms and conditions of the Creative Commons Attribution (CC BY) license (https:// creativecommons.org/licenses/by/ $4.0 /)$.

\begin{abstract}
The vast spread of multidrug-resistant bacteria has encouraged researchers to explore new antimicrobial compounds. This study aimed to investigate the phytochemistry and antibacterial activity of Cycas thouarsii R.Br. leaves extract against Klebsiella pneumoniae clinical isolates. The minimum inhibitory concentration (MIC) values of $C$. thouarsii extract ranged from 4 to $32 \mu \mathrm{g} / \mathrm{mL}$. The impact of the treatment of the isolates with sub-inhibitory concentrations of $C$. thouarsii extract was investigated on the bacterial growth, membrane integrity, inner and outer membrane permeability, membrane depolarization, and bacterial morphology using a scanning electron microscope (SEM) and on the efflux activity using qRT-PCR. Interestingly, most K. pneumoniae isolates treated with C. thouarsii extract showed growth inhibition-a decrease in membrane integrity. In addition, we observed various morphological changes, a significant increase in inner and outer membrane permeability, a non-significant change in membrane depolarization, and a decrease in efflux activity after treatment. The phytochemical investigation of $C$. thouarsii extract revealed the isolation of one new biflavonoid, $5,7,7^{\prime \prime}, 4^{\prime \prime \prime}$-tetra-O-methyl-hinokiflavone (3), and five known compounds, stigmasterol (1), naringenin (2), 2,3-dihydrobilobetin (4), $4^{\prime}, 4^{\prime \prime \prime}$-O-dimethyl amentoflavone (5), and hinokiflavone (6), for the first time. Moreover, the pure compounds ${ }^{\prime} \mathrm{MICs}^{\prime}$ ranged from 0.25 to $2 \mu \mathrm{g} / \mathrm{mL}$. Thus, $\mathrm{C}$. thouarsii could be a potential source for new antimicrobials.
\end{abstract}

Keywords: biflavonoids; efflux; membrane permeability; natural products; SEM; 5,7,7" ,4" -tetra-Omethyl-hinokiflavone

\section{Introduction}

Klebsiella pneumoniae is a Gram-negative, rod-shaped bacterium that belongs to the family Enterobacteriaceae [1]. It has emerged as an important opportunistic pathogen, causing nosocomial infections, especially in urinary, respiratory tracts, and blood [2]. Recently, multidrug resistance is highly disseminated among Klebsiella pneumoniae isolates causing serious problems at the clinical sites due to the decreased therapeutic options available to treat such resistant bacteria [3]. K. pneumoniae isolates could acquire different mechanisms that lead to antibiotic resistance to many antibiotics [4]. This concern has resulted in high mortality rates and extended hospitalization periods in patients infected with this pathogen [5]. Consequently, studies with alternative approaches, for example, herbal medicines, are emerging as a promising trend to combat such resistant isolates.

The Cycas thouarsii R.Br.'s family, Cycadaceae, is the only African representative of the Cycas, the Cycadaceae's sole genus. It is a widespread fast-growing species found mainly on Madagascar's east coast [6]. Recently, Cycas thouarsii was reported to display cytotoxic, antioxidant, and antimicrobial activities [7]. The Cycas genus contains a wide variety of flavonoids and biflavonoids as well as their glycosides, which are responsible 
for the activity of their plants [8-10]. Through the continuous search for new antibacterial agents from different plants, we aimed in this study to examine the antibacterial activity of Cycas thouarsii R.Br. leaves extract against Klebsiella pneumoniae clinical isolates. In addition, phytochemical investigation, the isolation of pure compounds, the antibacterial effect of the isolated compounds, and the effect on the bacterial membrane properties and efflux activity were investigated.

\section{Results}

2.1. Phytochemical Investigation

\subsubsection{Spectroscopic Data}

Compound (1): White crystal; m.p. (161-165 $\left.{ }^{\circ} \mathrm{C}\right)$, IR (KBr) $v_{\max }: 3449,2930,2861,1644$, 1462, 1377, 882, 830. ${ }^{1} \mathrm{H}$ NMR $\left[\mathrm{CDCl}_{3}, 500 \mathrm{MHz}\right] \delta: 3.52$ (1H, m, H-3), 5.35 (1H, t, H-6), $0.67(3 \mathrm{H}, \mathrm{s}, \mathrm{H}-18) 0.92(3 \mathrm{H}, \mathrm{d}, J=6.0 \mathrm{~Hz}, \mathrm{H}-19), 5.00$ (1H, m, H-20), 5.15 (1H, m, H-21), 0.84 $(3 \mathrm{H}, \mathrm{t}), 0.82(3 \mathrm{H}, \mathrm{d}, J=6.0 \mathrm{~Hz}, \mathrm{H}-26), 0.81(3 \mathrm{H}, \mathrm{d}, J=6.0 \mathrm{~Hz}, \mathrm{H}-27), 0.69$ (3H, s, H-28), 1.00 (3H, s, H-29). $\left.{ }^{13} \mathrm{C} \mathrm{NMR} \mathrm{[CDCl}, 125 \mathrm{MHz}\right] \delta: 37.22$ (C-1), 30.94 (C-2), 71.80 (C-3), 42.20 (C-4), 140.73 (C-5), 121.72 (C-6), 31.63 (C-7), 31.87 (C-8), 50.09 (C-9), 36.48 (C-10), 21.06 (C-11), 39.65 (C-12), 42.28 (C-13), 56.7 (C-14), 24.29 (C-15), 28.24 (C-16), 56.01 (C-17), 39.74 (C-18), 21.05 (C-19), 138.32 (C-20), 129.24 (C-21), 45.80 (C-22), 26.01 (C-23), 11.84 (C-24), 29.09 (C-25), 19.81 (C-26), 19.38 (C-27), 19.0 (C-28), 12.03 (C-29). EI-MS m/z 412.63 (M+), with a molecular formula of $\mathrm{C}_{29} \mathrm{H}_{48} \mathrm{O}$.

Compound (2): Slight yellow powder, IR (KBr) $v_{\text {max }}: 3957,3780,3290,3119,2918$, 2831, 2709, $1634 \mathrm{~cm}^{-1} .{ }^{1} \mathrm{H}$ NMR [DMSO-d 6 , $\left.500 \mathrm{MHz}\right] \delta_{\mathrm{H}}: 5.42(1 \mathrm{H}, \mathrm{dd}, J=12.5,3.5 \mathrm{~Hz}$, H-2), 3.30 (1H, dd, $J=17.0,12.5 \mathrm{~Hz}, \mathrm{H}-3 \mathrm{a}), 2.69(1 \mathrm{H}, \mathrm{dd}, J=17.0,3.5 \mathrm{~Hz}, \mathrm{H}-3 \mathrm{~b}), 5.88(2 \mathrm{H}$, $\mathrm{d}, J=2.0 \mathrm{~Hz}, \mathrm{H}-6,8), 7.31\left(2 \mathrm{H}, \mathrm{d}, J=8.0 \mathrm{~Hz}, \mathrm{H}-2^{\prime}, 6^{\prime}\right), 6.82\left(2 \mathrm{H}, \mathrm{d}, J=8.0 \mathrm{~Hz}, \mathrm{H}-3^{\prime}, 5^{\prime}\right)$, $12.15\left(\mathrm{OH}\right.$ at 5). ${ }^{13} \mathrm{C}$ NMR [DMSO- $\left.d_{6}, 125 \mathrm{MHz}\right] \delta_{\mathrm{C}}: 79.04(\mathrm{C}-2), 42.16(\mathrm{C}-3), 196.38(\mathrm{C}-4)$, 164.03 (C5), 95.86 (C-6), 166.92 (C-7), 94.80 (C-8), 163.45 (C-9), 101.94 (C-10), $129.66\left(\mathrm{C}-1^{\prime}\right)$, $127.63\left(\mathrm{C}-2^{\prime}, 6^{\prime}\right), 114.91\left(\mathrm{C}-3^{\prime}, 5^{\prime}\right), 157.56\left(\mathrm{C}-4^{\prime}\right)$ ESI-MS $m / z 271.223$ [M-H] ${ }^{-}$, with a molecular formula of $\mathrm{C}_{15} \mathrm{H}_{12} \mathrm{O}_{5}$.

Compound (3): Yellow amorphous powder, $[\alpha]^{25} \mathrm{D}=-27.38^{\circ}\left(\mathrm{CH}_{3} \mathrm{OH}, \mathrm{c}=0.5\right)$, IR (KBr disc) $v_{\text {max }}: 3451,3078,2939,2841,1981,1657,1606,1434,1373,1339,1262,1060,1028$, $835 \mathrm{~cm}^{-1} .{ }^{1} \mathrm{H} \mathrm{NMR}\left[\mathrm{CDCl}_{3}, 500 \mathrm{MHz}\right] \delta_{\mathrm{H}}: 6.66(1 \mathrm{H}, \mathrm{s}, \mathrm{H}-3), 6.36(1 \mathrm{H}, \mathrm{d}, J=2.5 \mathrm{~Hz}, \mathrm{H}-6)$, $6.44(1 \mathrm{H}, \mathrm{d}, J=2.5 \mathrm{~Hz}, \mathrm{H}-8), 6.61\left(1 \mathrm{H}, \mathrm{s}, \mathrm{H}-3^{\prime \prime}\right), 6.54\left(1 \mathrm{H}, \mathrm{s}, \mathrm{H}-8^{\prime \prime}\right), 7.88$ (2H, d, J = 8.5 Hz, $\left.\mathrm{H}-2^{\prime}, 6^{\prime}\right), 7.18\left(2 \mathrm{H}, \mathrm{d}, J=8.5 \mathrm{~Hz}, \mathrm{H}-3^{\prime}, 5^{\prime}\right), 7.48\left(2 \mathrm{H}, \mathrm{d}, J=8.5 \mathrm{~Hz}, \mathrm{H}-2^{\prime \prime \prime}, 6^{\prime \prime \prime}\right), 6.84(2 \mathrm{H}, \mathrm{d}$, $\left.J=8.5 \mathrm{~Hz}, \mathrm{H}-3^{\prime \prime \prime}, 5^{\prime \prime \prime}\right), 13.12\left(\mathrm{OH}\right.$ at 5") $, 3.79,3.81,3.84,3.86\left(\mathrm{OCH}_{3}\right.$ at 5, 7, 7", and $\left.4^{\prime \prime \prime}\right)$. ${ }^{13} \mathrm{C} \mathrm{NMR}\left[\mathrm{CDCl}_{3}, 125 \mathrm{MHz}\right] \delta_{\mathrm{C}}: 164.04(\mathrm{C}-2), 105.06(\mathrm{C}-3), 182.81(\mathrm{C}-4), 162.11(\mathrm{C} 5), 98.15$ (C-6), 162.52 (C-7), 92.62 (C-8), 157.70 (C-9), 104.57 (C-10), $131.07\left(\mathrm{C}-1^{\prime}\right), 127.73\left(\mathrm{C}-2^{\prime}\right), 111.19$ $\left(\mathrm{C}-3^{\prime}\right), 162.36\left(\mathrm{C}-4^{\prime}\right), 111.19\left(\mathrm{C}-5^{\prime}\right), 127.73\left(\mathrm{C}-6^{\prime}\right), 165.44\left(\mathrm{C}-2^{\prime \prime}\right), 103.56\left(\mathrm{C}-3^{\prime \prime}\right), 182.37\left(\mathrm{C}-4^{\prime \prime}\right)$, 155.10 (C-5"), 123.34 (C-6"), 157.70 (C-7") 94.43 (C-8"), 154.09 (C-9"), 105.52 (C-10"), 127.98 $\left(\mathrm{C}-1^{\prime \prime \prime}\right), 128.00\left(\mathrm{C}-2^{\prime \prime \prime}, 6^{\prime \prime \prime}\right), 114.48\left(\mathrm{C}-3^{\prime \prime \prime}, 5^{\prime \prime \prime}\right), 160.65\left(\mathrm{C}-4^{\prime \prime \prime}\right), 56.33,55.94,55.79,55.48\left(\mathrm{OCH}_{3}\right.$ at C-5, 7, 7", and $4^{\prime \prime \prime}$ ); Data assigned by COSY and HMBC. ESI-MS m/z 593.3633 [M-H] ${ }^{-}$, with a molecular formula of $\mathrm{C}_{34} \mathrm{H}_{26} \mathrm{O}_{10}$.

Compound (4): Yellowish white amorphous powder; IR (KBr) $v_{\max }$ : 3418, 2958, 2928, 1729, 1655, 1605, 874. ${ }^{1} \mathrm{H}$ NMR [DMSO-d $6,500 \mathrm{MHz}$ ] $\delta_{\mathrm{H}}: 5.36-5.63(1 \mathrm{H}, \mathrm{m}, \mathrm{H}-2), 3.20-3.32$ (1H, m, H-3a), 2.67-2.92 (1H, m, H-3b), $5.81(1 \mathrm{H}, \mathrm{m}, \mathrm{H}-6), 5.91(1 \mathrm{H}, \mathrm{m}, \mathrm{H}-8), 7.46-7.52$ $\left(2 \mathrm{H}, \mathrm{m}, \mathrm{H}-2^{\prime}, 6^{\prime}\right), 7.40\left(1 \mathrm{H}, \mathrm{d}, J=8.0 \mathrm{~Hz}, \mathrm{H}-5^{\prime}\right), 6.51\left(1 \mathrm{H}, \mathrm{s}, \mathrm{H}-3^{\prime \prime}\right), 6.25\left(1 \mathrm{H}, \mathrm{s}, \mathrm{H}-6^{\prime \prime}\right), 7.41$ $\left(2 \mathrm{H}, \mathrm{dd}, J=8.0,3.0 \mathrm{~Hz}, \mathrm{H}-2^{\prime \prime \prime}, 6^{\prime \prime \prime}\right), 6.65-6.70\left(2 \mathrm{H}, \mathrm{m}, \mathrm{H}-3^{\prime \prime \prime}, 5^{\prime \prime \prime}\right), 3.65\left(\mathrm{OCH}_{3}\right.$ at $\left.4^{\prime}\right) .{ }^{13} \mathrm{C}$ NMR $\left[\mathrm{DMSO}-d_{6}, 125 \mathrm{MHz}\right] \delta_{\mathrm{C}}: 79.08$ (C-2), 43.16 (C-3), 192.23 (C-4), 164.33 (C5), 95.70 (C-6), 166.52 (C-7), 94.87 (C-8), 163.45 (C-9), $101.73(\mathrm{C}-10), 130.66\left(\mathrm{C}-1^{\prime}\right), 131.33\left(\mathrm{C}-2^{\prime}\right), 121.19$ $\left(\mathrm{C}-3^{\prime}\right), 158.26\left(\mathrm{C}-4^{\prime}\right), 110.70\left(\mathrm{C}-5^{\prime}\right), 127.97\left(\mathrm{C}-6^{\prime}\right), 164.08\left(\mathrm{C}-2^{\prime \prime}\right), 102.63\left(\mathrm{C}-3^{\prime \prime}\right), 184.23\left(\mathrm{C}-4^{\prime \prime}\right)$, 164.33 (C5"), 98.36 (C-6"), 162.52 (C-7"), 104.57 (C-8"), 155.45 (C-9"), 104.50 (C-10"), 122.66 $\left(\mathrm{C}-1^{\prime \prime \prime}\right), 127.92\left(\mathrm{C}-2^{\prime \prime \prime}, 6^{\prime \prime \prime}\right), 115.49\left(\mathrm{C}-3^{\prime \prime \prime}, 5^{\prime \prime \prime}\right), 161.31\left(\mathrm{C}-4^{\prime \prime \prime}\right), 54.78\left(\mathrm{OCH}_{3}\right.$ at $\left.\mathrm{C}-4^{\prime}\right)$. ESI-MS $m / z 553.269[\mathrm{M}-\mathrm{H}]^{-}$, with a molecular formula of $\mathrm{C}_{31} \mathrm{H}_{22} \mathrm{O}_{10}$.

Compound (5): Yellow amorphous powder; IR (KBr) $v_{\max }$ : 3396, 2966, 2925, 2859, $2318,1656,1602,1440,1379,1339,1256,1093,882,836 .{ }^{1} \mathrm{H}$ NMR [DMSO- $\left.d_{6}, 500 \mathrm{MHz}\right]$ 
$\delta_{\mathrm{H}}: 6.92(1 \mathrm{H}, \mathrm{s}, \mathrm{H}-3), 6.18(1 \mathrm{H}, \mathrm{d}, J=2.0 \mathrm{~Hz}, \mathrm{H}-6), 6.47(1 \mathrm{H}, \mathrm{d}, J=2.0 \mathrm{~Hz}, \mathrm{H}-8), 8.06(1 \mathrm{H}$, $\left.\mathrm{d}, J=2.0 \mathrm{~Hz}, \mathrm{H}-2^{\prime}\right), 7.31\left(1 \mathrm{H}, \mathrm{d}, J=9.0 \mathrm{~Hz}, \mathrm{H}-5^{\prime}\right), 8.18\left(1 \mathrm{H}, \mathrm{dd}, J=2.0,9.0 \mathrm{~Hz}, \mathrm{H}-6^{\prime}\right), 6.78$ $\left(1 \mathrm{H}, \mathrm{s}, \mathrm{H}-3^{\prime \prime}\right), 6.38\left(1 \mathrm{H}, \mathrm{s}, \mathrm{H}-6^{\prime \prime}\right), 7.50\left(2 \mathrm{H}, \mathrm{d}, J=8.5 \mathrm{~Hz}, \mathrm{H}-2^{\prime \prime \prime}, 6^{\prime \prime \prime}\right), 6.71(2 \mathrm{H}, \mathrm{d}, J=8.5 \mathrm{~Hz}$, $\left.\mathrm{H}-3^{\prime \prime \prime}, 5^{\prime \prime \prime}\right), 10.28,10.84 \mathrm{OH}$ at C7, $\left.7^{\prime \prime}\right), 3.77,3.79\left(\mathrm{OCH}_{3}\right.$ at $\left.4^{\prime}, 4^{\prime \prime \prime}\right) .{ }^{13} \mathrm{C} \mathrm{NMR} \mathrm{[DMSO}-d_{6}$, $125 \mathrm{MHz}] \delta_{\mathrm{C}}: 163.61$ (C-2), 103.60 (C-3), 182.11 (C-4), 161.46 (C5), 98.59 (C-6), 163.40 (C-7), 94.15 (C-8), 157.45 (C-9), 103.63 (C-10), $121.66\left(\mathrm{C}-1^{\prime}\right), 128.30\left(\mathrm{C}-2^{\prime}\right), 121.27\left(\mathrm{C}-3^{\prime}\right), 160.64$ $\left(\mathrm{C}-4^{\prime}\right), 111.71\left(\mathrm{C}-5^{\prime}\right), 130.61\left(\mathrm{C}-6^{\prime}\right), 164.25\left(\mathrm{C}-2^{\prime \prime}\right), 103.36\left(\mathrm{C}-3^{\prime \prime}\right), 181.82\left(\mathrm{C}-4^{\prime \prime}\right), 160.48\left(\mathrm{C} 5^{\prime \prime}\right)$, $98.94\left(\mathrm{C}-6^{\prime \prime}\right), 161.81\left(\mathrm{C}-7^{\prime \prime}\right), 104.60\left(\mathrm{C}-8^{\prime \prime}\right), 154.32\left(\mathrm{C}-9^{\prime \prime}\right), 103.70\left(\mathrm{C}-10^{\prime \prime}\right), 122.48\left(\mathrm{C}-1^{\prime \prime \prime}\right), 128.17$ $\left(\mathrm{C}-2^{\prime \prime \prime}\right), 115.66\left(\mathrm{C}-3^{\prime \prime \prime}\right), 161.10\left(\mathrm{C}-4^{\prime \prime \prime}\right), 115.83\left(\mathrm{C}-5^{\prime \prime}\right), 128.08\left(\mathrm{C}-6^{\prime \prime \prime}\right), 56.03,55.93\left(\mathrm{OCH}_{3}\right.$ at $\left.\mathrm{C}-4^{\prime}, 4^{\prime \prime \prime}\right)$. ESI-MS m/z $565.362[\mathrm{M}-\mathrm{H}]^{-}$, with a molecular formula of $\mathrm{C}_{32} \mathrm{H}_{22} \mathrm{O}_{10}$.

Compound (6): Yellow amorphous powder IR (KBr disc) $v_{\max }: 3450,2927,2858,2358$, 1643, 1430, 1364, 1287, $835 \mathrm{~cm}^{-1} .{ }^{1} \mathrm{H}$ NMR [DMSO-d $6,500 \mathrm{MHz}$ ] $\delta_{\mathrm{H}}: 6.83(1 \mathrm{H}, \mathrm{s}, \mathrm{H}-3), 6.17$ $(1 \mathrm{H}, \mathrm{d}, J=2.0 \mathrm{~Hz}, \mathrm{H}-6), 6.43(1 \mathrm{H}, \mathrm{d}, J=2.0 \mathrm{~Hz}, \mathrm{H}-8), 6.77\left(1 \mathrm{H}, \mathrm{s}, \mathrm{H}-3^{\prime \prime}\right), 6.34\left(1 \mathrm{H}, \mathrm{s}, \mathrm{H}-8^{\prime \prime}\right), 8.04$ $\left(2 \mathrm{H}, \mathrm{d}, J=8.5 \mathrm{~Hz}, \mathrm{H}-2^{\prime}, 6^{\prime}\right), 7.08\left(2 \mathrm{H}, \mathrm{d}, J=8.5 \mathrm{~Hz}, \mathrm{H}-3^{\prime}, 5^{\prime}\right), 7.97\left(2 \mathrm{H}, \mathrm{d}, J=8.5 \mathrm{~Hz}, \mathrm{H}-2^{\prime \prime \prime}\right.$, $\left.6^{\prime \prime \prime}\right), 6.86\left(2 \mathrm{H}, \mathrm{d}, J=8.5 \mathrm{~Hz}, \mathrm{H}-3^{\prime \prime \prime}, 5^{\prime \prime \prime}\right) .{ }^{13} \mathrm{C}$ NMR [DMSO-d $\left.6,125 \mathrm{MHz}\right] \delta_{\mathrm{C}}: 163.95(\mathrm{C}-2)$, 103.67 (C-3), 181.33 (C-4), 161.43 (C5), 98.82 (C-6), 163.52 (C-7), 94.03 (C-8), 157.10 (C-9), 103.52 (C-10), $124.27\left(\mathrm{C}-1^{\prime}\right), 127.75\left(\mathrm{C}-2^{\prime}\right), 115.19\left(\mathrm{C}-3^{\prime}\right), 162.52\left(\mathrm{C}-4^{\prime}\right), 115.19\left(\mathrm{C}-5^{\prime}\right), 127.75$ $\left(\mathrm{C}-6^{\prime}\right), 164.09$ (C-2"), 103.26 (C-3"), 182.03 (C-4"), $155.11\left(\mathrm{C}-5^{\prime \prime}\right), 124.34\left(\mathrm{C}-6^{\prime \prime}\right), 157.33$ (C-7"), $94.61\left(\mathrm{C}-8^{\prime \prime}\right), 153.59$ (C-9") $104.52\left(\mathrm{C}-10^{\prime \prime}\right), 121.51\left(\mathrm{C}-1^{\prime \prime \prime}\right), 128.20\left(\mathrm{C}-2^{\prime \prime \prime}, 6^{\prime \prime \prime}\right), 116.12\left(\mathrm{C}-3^{\prime \prime \prime}\right.$, $\left.5^{\prime \prime \prime}\right), 160.51\left(\mathrm{C}-4^{\prime \prime \prime}\right)$. ESI-MS $m / z 537.082[\mathrm{M}-\mathrm{H}]^{-}$, with a molecular formula of $\mathrm{C}_{30} \mathrm{H}_{18} \mathrm{O}_{10}$.

\subsubsection{Structure Elucidation of the Isolated New Compound (3)}

Dried leaves of Cycas thouarsii were extracted with methanol by cold maceration and then successively partitioned with $n$-hexane, dichloromethane, ethyl acetate, and n-butanol, respectively. The dichloromethane fraction residue (DCM) was subjected to different columns chromatography to yield six compounds. Their chemical structures were identified by spectroscopic analysis (1D, 2D NMR, and ESI/MS) and comparison with the reported data.

Compound (3) is a new biflavonoid, and the ${ }^{1} \mathrm{H}-\mathrm{NMR}$ of 3 established the presence of only one hydroxyl group that resonated at $\delta 13.12$, indicating the presence of one chelated hydroxyl at the $5^{\prime \prime}$ position. The ${ }^{1} \mathrm{H}-\mathrm{NMR}$ spectrum also showed two sets of the $\mathrm{AA}^{\prime} \mathrm{BB}^{\prime}$ systems as indicated by $\delta 7.48(2 \mathrm{H}, \mathrm{d}, J=8.5 \mathrm{~Hz})$ for $\mathrm{H}-2^{\prime \prime \prime}, 6^{\prime \prime \prime}, \delta 6.84(2 \mathrm{H}, \mathrm{d}, J=8.5 \mathrm{~Hz})$ for $\mathrm{H}-3^{\prime \prime \prime}, 5^{\prime \prime \prime}$ and $7.88(2 \mathrm{H}, \mathrm{d}, J=8.5 \mathrm{~Hz})$ for $\mathrm{H}-2^{\prime}, 6^{\prime}$, and $\delta 7.18(2 \mathrm{H}, \mathrm{d}, J=8.5 \mathrm{~Hz})$ for $\mathrm{H}-3^{\prime}$, $5^{\prime}$. The presence of two meta-coupled doublets $(J=2.5 \mathrm{~Hz})$ each due to the one proton in the upfield aromatic region at $\delta 6.36$ and 6.44 was ascribed to the H- 6 and H-8 protons, respectively. Moreover, the three-singlet signals at $\delta 6.54,6.61$, and 6.66 were assigned to $\mathrm{H}-8^{\prime \prime}, \mathrm{H}-3^{\prime \prime}$, and $\mathrm{H}-3$, suggesting the biflavonoid linkage between $4^{\prime}-\mathrm{OH}$ and $6^{\prime \prime}$. The ${ }^{1} \mathrm{H}-\mathrm{NMR}$ spectrum revealed a hinokiflavone pattern (a diaryl ether-type biflavonoid) with four aromatic methoxy signals at $\delta 3.79,3.81,3.84$, and 3.86, suggesting tetra-O-methyl derivatives. The ${ }^{13} \mathrm{C}$-NMR spectrum further confirmed the biflavonoid structure from the presence of 30 carbons in addition to four methoxy signals at $\delta 56.33,55.94,55.79$, and $55.48 \mathrm{ppm}$. The ${ }^{13} \mathrm{C}$-NMR spectrum showed the presence of one signal at $\delta 92.62$ and two signals at $\delta 98.15$ and 95.43 assigned to $C-8, C-6$, and $C-8^{\prime \prime}$, respectively. This implies that $C-6^{\prime \prime}$ is involved in the interflavonoid linkage, which also confirmed the hinokiflavone pattern [11]. Hinokiflavone $O$-methylation affects the shift of ortho- and para-atoms, as the ${ }^{13} \mathrm{C}-\mathrm{NMR}$ spectrum revealed a downfield shift in C-10, an upfield shift in C-8 indicating 7-O-methoxylation, a downfield shift in C-10", and an upfield shift in C-8 $8^{\prime \prime}$ indicating $7^{\prime \prime}$-Omethoxylation. While there was an upfield shift in $C-3^{\prime \prime \prime}, 5^{\prime \prime \prime}$, there was a downfield shift in $\mathrm{C}-1^{\prime \prime \prime}$, indicating $4^{\prime \prime \prime}$-O-methoxylation compared with hinokiflavone (6) [12]. The tetra-Omethyl-hinokiflavone structure confirmed with $\mathrm{HMBC}$ correlations from $\mathrm{OCH}_{3}-7$ at $\delta 3.86$ to $\mathrm{C}-7$ at $\delta 162.52$, from $\mathrm{OCH}_{3}-7^{\prime \prime}$ at $\delta 3.84$ to $\mathrm{C}-7^{\prime \prime}$ at $\delta 157.70$, from $\mathrm{OCH}_{3}-4^{\prime \prime \prime}$ at $\delta 3.81$ to $\mathrm{C}-4^{\prime \prime \prime}$ at $\delta 160.65$, from $\mathrm{OCH}_{3}-5$ at $\delta 3.79$ to $\mathrm{C}-5$ at $\delta 162.11$, and from $\mathrm{OH}-5^{\prime \prime}$ at $\delta 13.12$ to $\mathrm{C}-6^{\prime \prime}$ at $\delta 123.34$ and $C-10^{\prime \prime}$ at $\delta 105.52$ [13]. All correlations are displayed in Figure 1A. The ESIMS spectrum of this compound showed ion at $m / z 593.3633[\mathrm{M}-\mathrm{H}]^{-}$which matches with 
the determined structure. Only mono-methoxy (isocryptomerin and cryptomerin B) and di-methoxy (chamaecyparin) derivatives of hinokiflavone were isolated from plants [12,14] Thus, this compound was identified as 5,7,7", $4^{\prime \prime \prime}$-tetra-O-methyl-hinokiflavone (3) and considered a new compound isolated for the first time from all plants. Other isolated known compounds were identified as stigmasterol (1) [8], naringenin (2) [9], 2,3-dihydrobilobetin (4) [10], 4', $4^{\prime \prime \prime}$-O-dimethyl amentoflavone or isoginkgetin (5) [10], hinokiflavone (6) [12] for the first time from $C$. thouarsii $\mathrm{R}$.Br. leaves extract. The chemical structures of the isolated compounds are displayed in Figure 1.
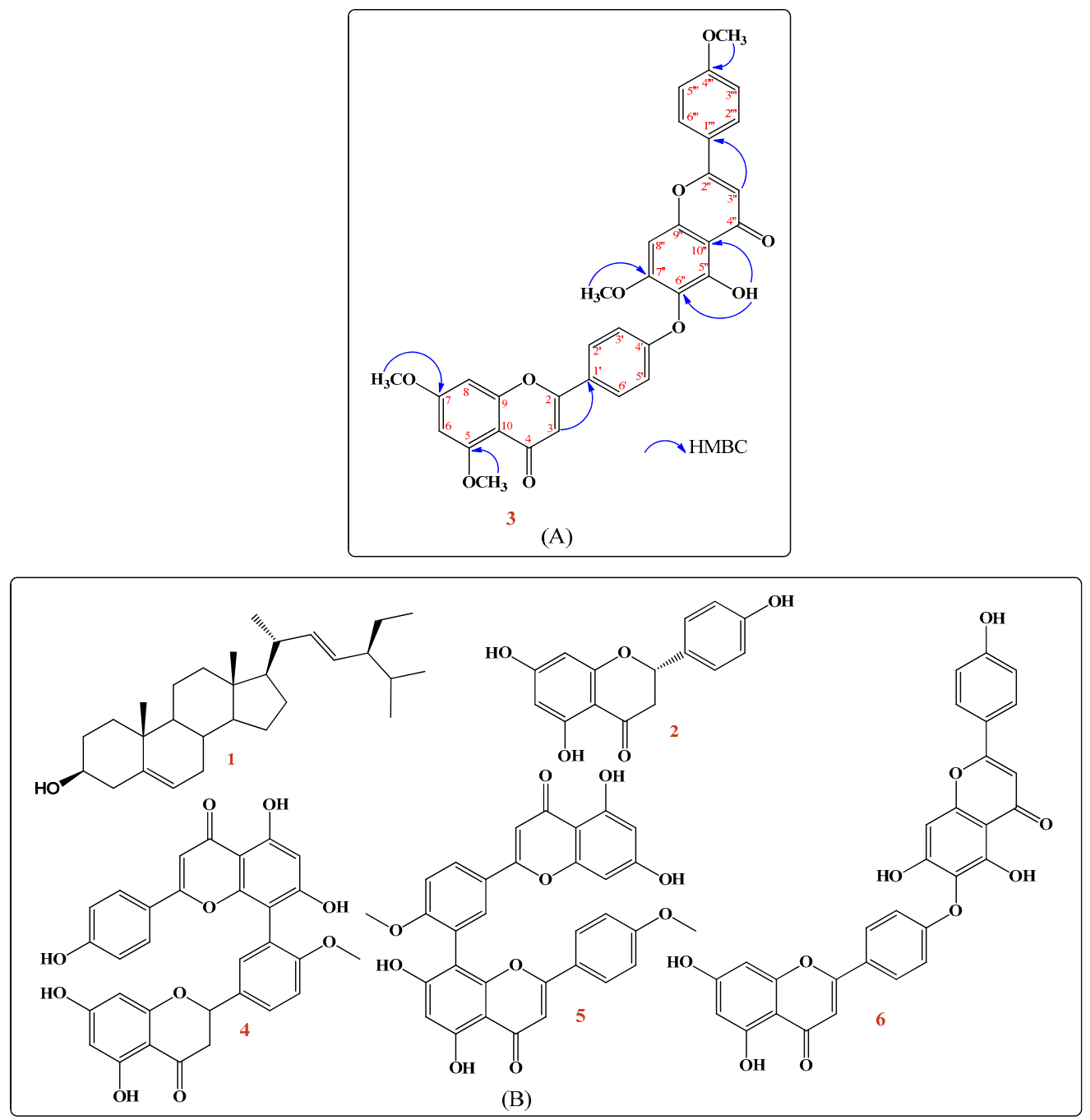

Figure 1. (A): The chemical structure of the new compound (3) showing HMBC correlations. (B): The chemical structures of isolated pure compounds.

\subsection{Biological Investigation}

C. thouarsii extract exhibited an antibacterial effect on the tested K. pneumoniae isolates using the agar well diffusion method. The minimum inhibitory concentration (MIC) values for the $C$. thouarsii extract were determined by the broth microdilution method, and they ranged from 4 to $32 \mu \mathrm{g} / \mathrm{mL}$.

\subsubsection{Bacterial Growth Curve}

C. thouarsii extract (at concentrations ranging from 2 to $16 \mu \mathrm{g} / \mathrm{mL}$ ) inhibited the growth cycle curve and decreased the growth in $73.5 \%$ of the tested isolates using a spectrophotometric method [15]. A representative example is shown in Figure 2. 


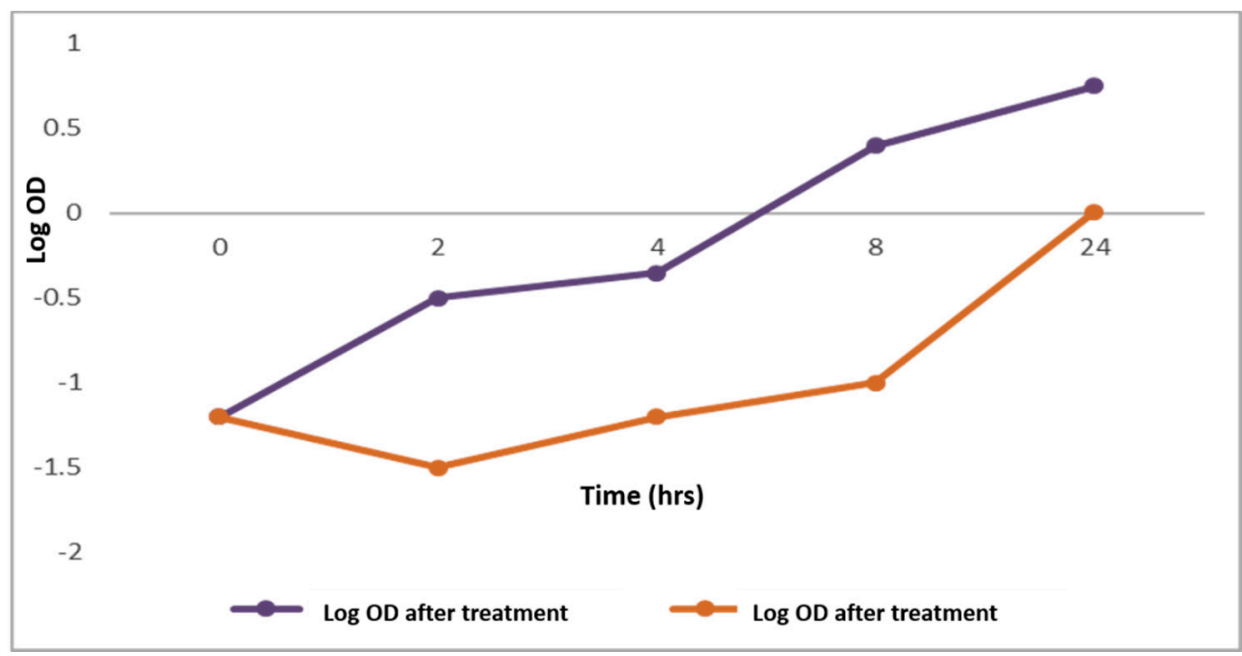

Figure 2. Growth curve of $K$. pneumoniae representative isolates before and after treatment with C. thouarsii extract $(16 \mu \mathrm{g} / \mathrm{mL})$.

\subsubsection{Integrity of Cell Membranes}

The integrity of the tested bacterial membranes was investigated before and after treatment with $C$. thouarsii extract (at concentrations ranging from 2 to $16 \mu \mathrm{g} / \mathrm{mL}$ ) via monitoring the release of the material, absorbing at $260 \mathrm{~nm}$, from the tested bacteria [16]. A significant decrease in membrane integrity (Figure 3) was detected in $73.5 \%$ of the treated cells.

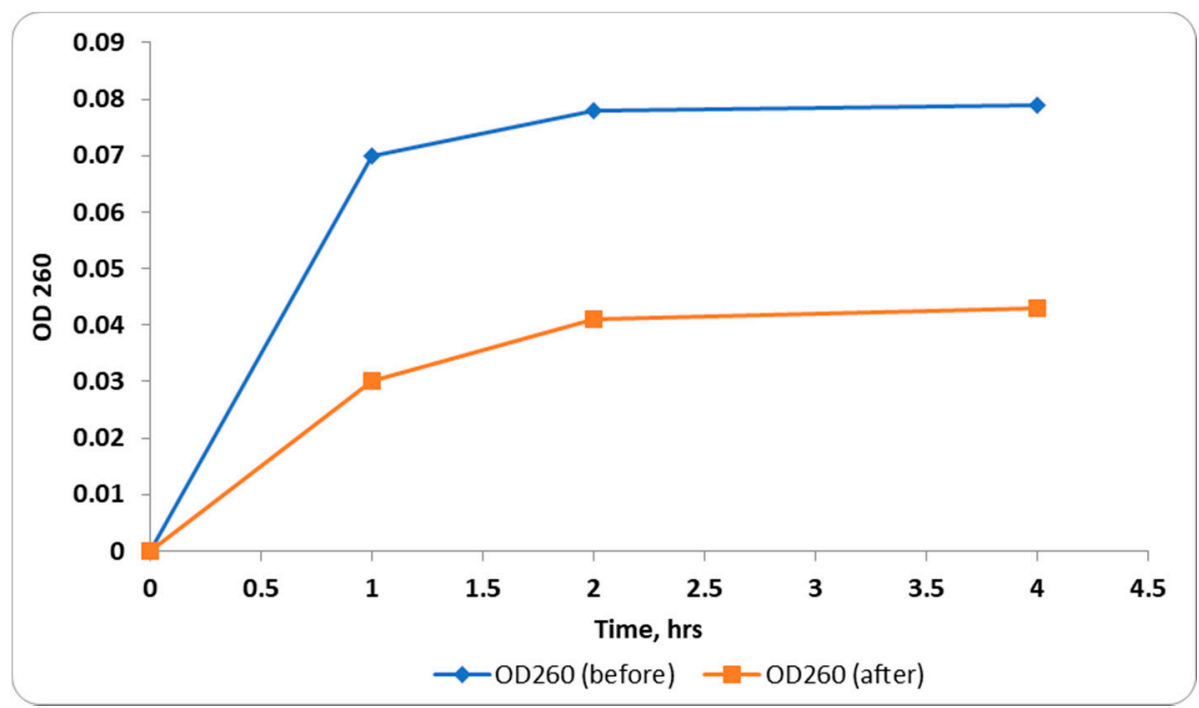

Figure 3. Release of $260 \mathrm{~nm}$ absorbing material from representative K. pneumoniae isolates before and after treatment with $C$. thouarsii extract $(16 \mu \mathrm{g} / \mathrm{mL})$.

\subsubsection{Inner Membrane Permeability Assay}

When the inner membrane of the tested bacterial cells is permeable, ortho-nitrophenyl- $\beta$ galactopyranoside (ONPG) enters the cytoplasm and is broken down by the $\beta$-galactosidase enzyme to ortho-nitrophenol (ONP, yellow color). The production of ONP was monitored by determination of the increase in the absorbance (at an optical density (OD) of 420) with time [17] as demonstrated in Figure 4. A significant increase in the inner membrane permeability was detected after treatment with $C$. thouarsii extract (at concentrations ranging from 2 to $16 \mu \mathrm{g} / \mathrm{mL}$ ) in $67.6 \%$ of isolates. 


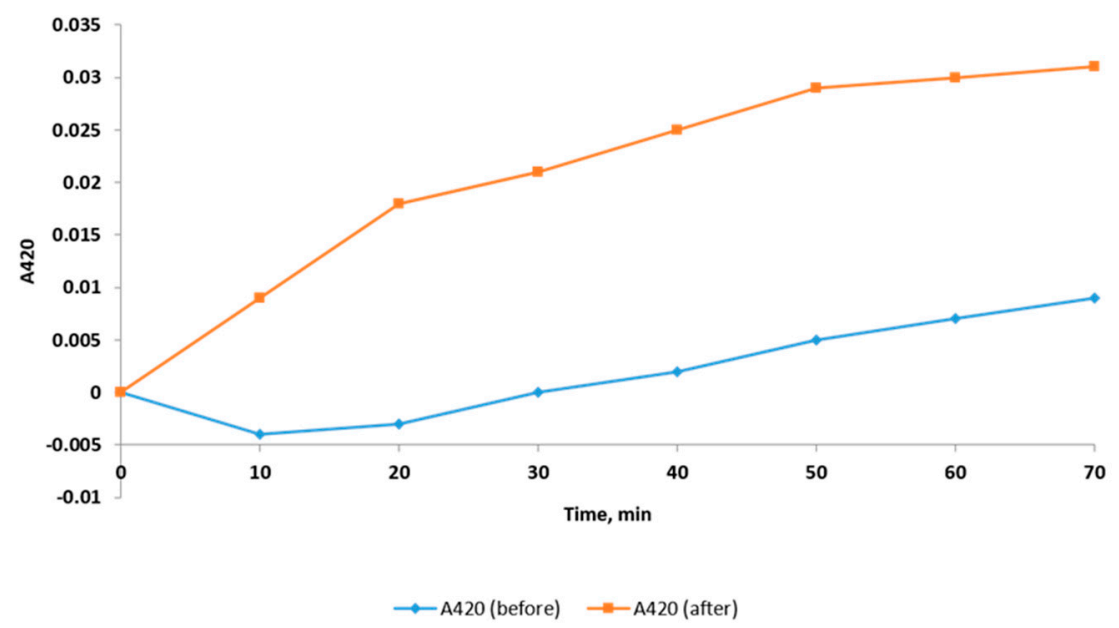

Figure 4. Representative example of change in the inner membrane permeability of K. pneumoniae isolates before and after treatment with $C$. thouarsii extract $(16 \mu \mathrm{g} / \mathrm{mL})$.

\subsubsection{Outer Membrane Permeability}

Outer membrane permeability was measured by recording the fluorescence of the hydrophobic agent 1-N-phenylnaphthylamine (NPN) using a spectrofluorophotometer [18]. The NPN fluorescence is detectable in hydrophobic environments such as the hydrophobic region of the cell membrane. As shown in Figure 5, a significant increase in the fluorescence of NPN, hence, the outer membrane permeability, was found in $58.8 \%$ of the treated isolates (concentrations of $C$. thouarsii extract ranged from 2 to $16 \mu \mathrm{g} / \mathrm{mL}$ ).

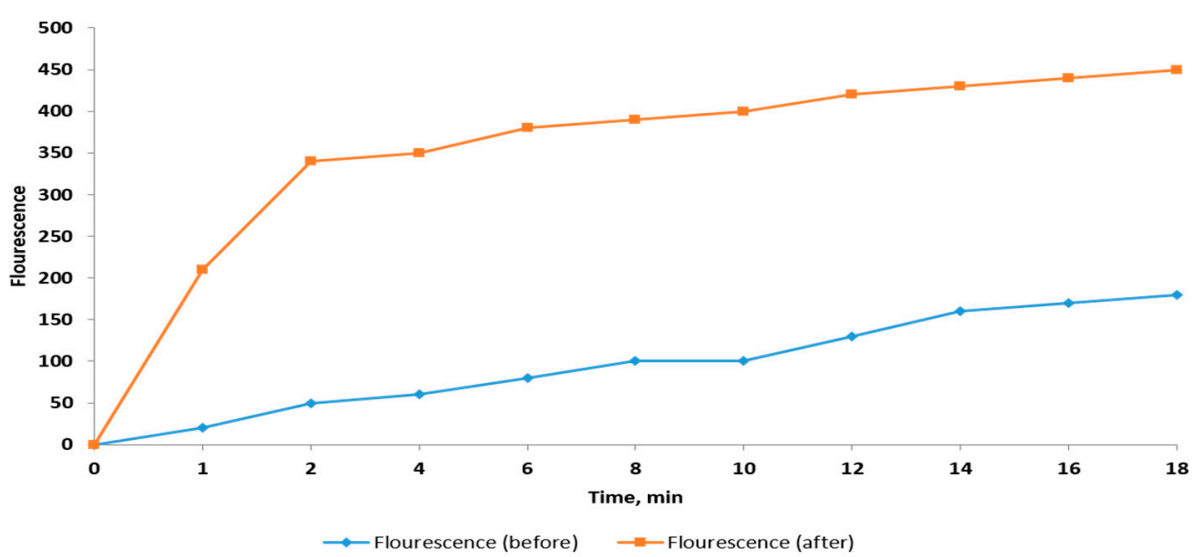

Figure 5. Representative example of the change in the outer membrane permeability of K. pneumoniae isolates before and after treatment with $C$. thouarsii extract $(16 \mu \mathrm{g} / \mathrm{mL})$.

\subsubsection{Membrane Depolarization Assay}

Flow cytometry was utilized to obtain a quantitative prospect regarding the impact of C. thouarsii extract on membrane depolarization of the tested bacterial isolates. Flow cytometric measurements were conducted on the tested cells after staining with bis-(1,3-dibutyl barbituric acid) trimethineoxonol [DiBAC4(3)], an anionic membrane potential-sensitive fluorescent agent that can access the depolarized cells where it binds to the membrane or intracellular proteins exhibiting enhanced fluorescence [17,19]. A non-significant change in the membrane depolarization after treatment with C. thouarsii extract (at concentrations ranging from 2 to $16 \mu \mathrm{g} / \mathrm{mL}$ ). A representative example of the flow cytometric dot plots and histograms before and after treatment are revealed in Figure 6. 

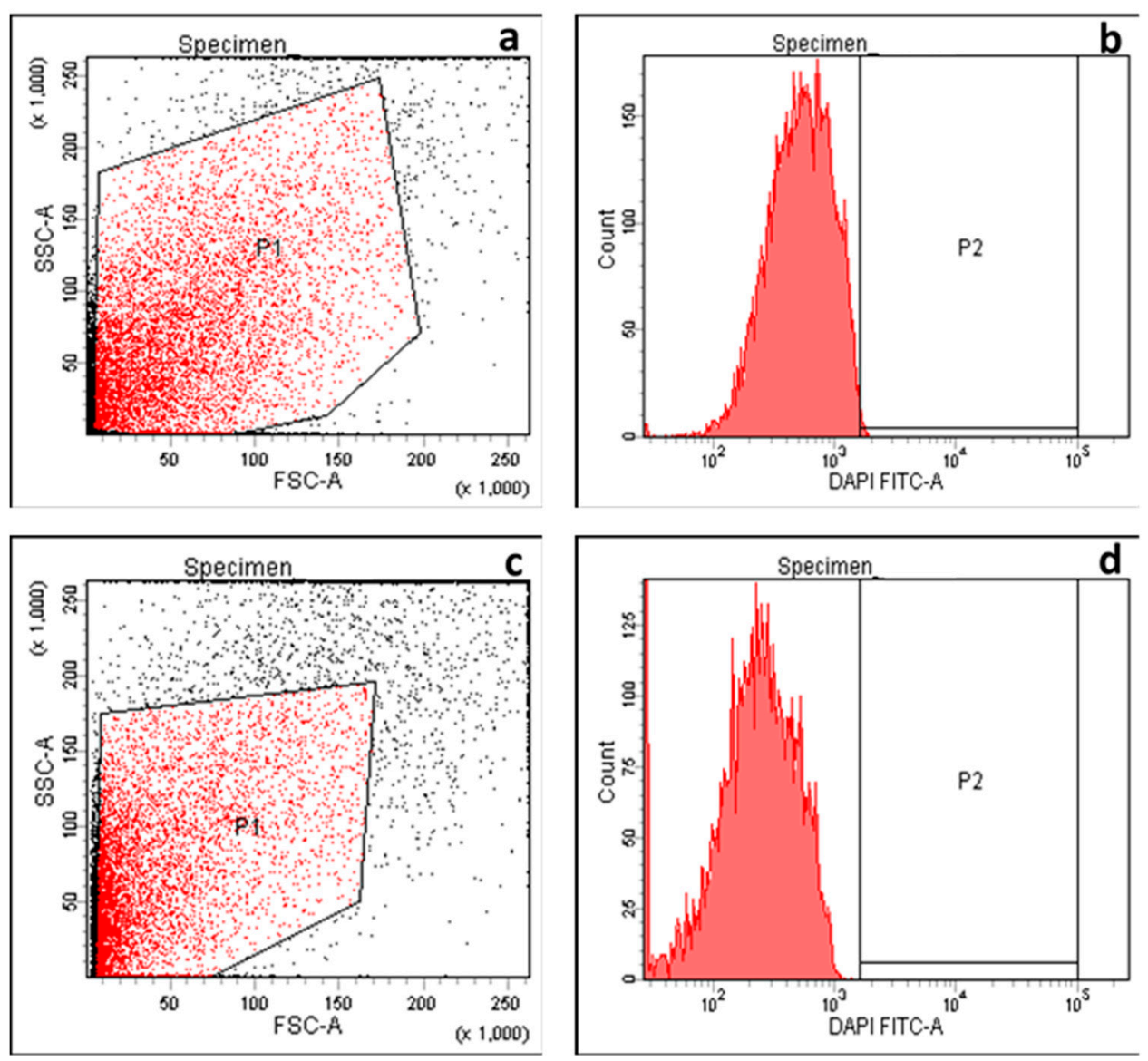

Figure 6. Flow cytometric dot plot and histogram showing fluorescence detected by a FACSverse flow cytometer in a representative K. pneumoniae isolate before treatment (dot plot (a) and histogram (b)) and after treatment (dot plot (c) and histogram (d)) with C. thouarsii extract $(16 \mu \mathrm{g} / \mathrm{mL})$.

\subsubsection{Scanning Electron Microscope (SEM) Examination}

The impact of $C$. thouarsii extract (at concentrations ranging from 2 to $16 \mu \mathrm{g} / \mathrm{mL}$ ) on the bacterial morphology was studied using SEM [20]. As shown in Figure 7, many morphological alterations were revealed involving wrinkling of the cell surface. In addition, disruption of the cell wall was noticed represented by the appearance of certain holes and cracks or even total cell lysis. Moreover, certain clusters of lysed cells were detected.
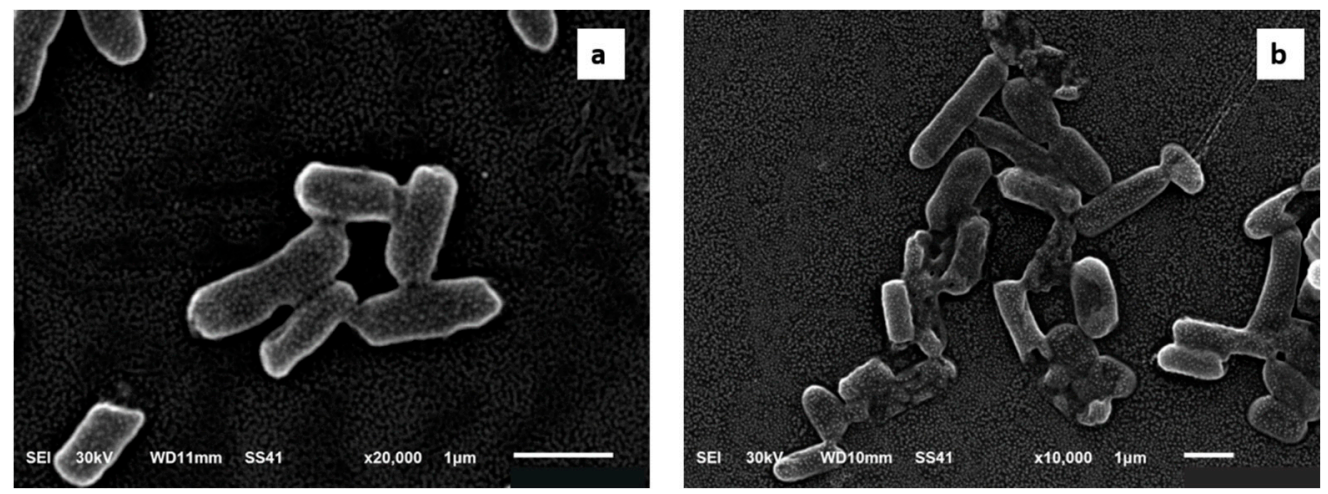

Figure 7. Scanning electron microscope image of a representative K. pneumoniae isolates (a) before and (b) after treatment with $C$. thouarsii extract $(16 \mu \mathrm{g} / \mathrm{mL})$. 


\subsubsection{Detection of Efflux}

In the present study, K. pneumoniae isolates showed a decrease in the efflux activity after treatment with $C$. thouarsii extract $(16 \mu \mathrm{g} / \mathrm{mL})$ as shown in Table 1. Isolates lacking efflux activity fluoresced at an ethidium bromide (EtBr) concentration of $0.5 \mathrm{mg} / \mathrm{L}$ [21].

Table 1. Efflux pump activity before and after treatment with C. thouarsii extract at different concentrations of EtBr using the cartwheel method.

\begin{tabular}{ccc}
\hline EtBr Concentration $(\mathrm{mg} / \mathrm{L}) *$ & $\begin{array}{c}\text { Number of Bacterial Isolates } \\
\text { (before Treatment) }\end{array}$ & $\begin{array}{c}\text { Number of Bacterial Isolates } \\
\text { (after Treatment) }\end{array}$ \\
\hline$\leq 0.5$ & 10 & 23 \\
1 & 11 & 4 \\
1.5 & 9 & 6 \\
2 & 4 & 1
\end{tabular}

${ }^{*}$ Concentration at which bacteria started to fluoresce considering the bacterial isolates lacking the efflux activity if it fluoresced at $0.5 \mathrm{mg} / \mathrm{L}$ and having an efflux activity if it fluoresced at higher concentrations.

\subsubsection{Quantitative RT-PCR}

To determine the impact of $C$. thouarsii extract on the efflux pump systems, the expression of four efflux pump genes in nine K. pneumoniae isolates before and after treatment with C. thouarsii extract ( 2 to $16 \mu \mathrm{g} / \mathrm{mL}$ ) was inspected, and the results are shown in Table 2. Melting curve analysis was used to evaluate primer-dimers and other artifacts.

Table 2. Relative gene expression (mean \pm SD) for the tested K. pneumoniae isolates after treatment with C. thouarsii extract $(2-16 \mu \mathrm{g} / \mathrm{mL})$.

\begin{tabular}{|c|c|c|c|c|}
\hline \multirow[t]{2}{*}{ Isolate Code } & \multicolumn{4}{|c|}{ Relative Gene Expression * } \\
\hline & norE & $\operatorname{acr} \mathrm{B}$ & $m d f \mathrm{~A}$ & yihV \\
\hline K1 & $0.1 \pm 0.3$ & $1.2 \pm 0.4$ & $1.1 \pm 0.3$ & $0.3 \pm 0.2$ \\
\hline $\mathrm{K} 2$ & $0.4 \pm 0.2$ & $0.3 \pm 0.1$ & $0.5 \pm 0.2$ & $0.4 \pm 0.3$ \\
\hline K3 & $1.1 \pm 0.1$ & $1.5 \pm 0.1$ & $0.6 \pm 0.1$ & $1.5 \pm 0.2$ \\
\hline K4 & $1.2 \pm 0.3$ & $0.5 \pm 0.1$ & $0.1 \pm 0.1$ & $0.6 \pm 0.2$ \\
\hline K5 & $0.5 \pm 0.1$ & $0.3 \pm 0.2$ & $0.3 \pm 0.4$ & $1.1 \pm 0.2$ \\
\hline K6 & $1.3 \pm 0.2$ & $1.2 \pm 0.1$ & $1.2 \pm 0.8$ & $1.6 \pm 0.1$ \\
\hline K7 & $1.1 \pm 0.3$ & $0.6 \pm 0.0$ & $1.3 \pm 0.2$ & $0.4 \pm 0.2$ \\
\hline K8 & $1.4 \pm 0.0$ & $0.2 \pm 0.5$ & $1.4 \pm 1.1$ & $1.4 \pm 0.3$ \\
\hline K9 & $0.9 \pm 0.2$ & $1.4 \pm 0.2$ & $0.3 \pm 0.0$ & $0.2 \pm 0.2$ \\
\hline
\end{tabular}

\subsubsection{Antimicrobial Activity of Different Fractions and Isolated Pure Compounds}

Different fractions of $C$. thouarsii exhibited antibacterial activity against $K$. pneumoniae clinical isolates with MIC values ranging from 16 to $512 \mu \mathrm{g} / \mathrm{mL}$. The DCM fraction had the highest activity $(16-32 \mu \mathrm{g} / \mathrm{mL})$, followed by ethyl acetate $(32-128 \mu \mathrm{g} / \mathrm{mL})$, then $n$-butanol fraction $(128-512 \mu \mathrm{g} / \mathrm{mL})$, while the $n$-hexane fraction exhibited the lowest antibacterial activity (256-1024 $\mu \mathrm{g} / \mathrm{mL}$ ). The MIC values of the pure isolated compounds ranged from 0.25 to $2 \mu \mathrm{g} / \mathrm{mL}$. Among the isolated compounds, hinokiflavone (6) presented the highest activity $(0.25-0.5 \mu \mathrm{g} / \mathrm{mL})$, followed by naringenin (2) $(0.5-1 \mu \mathrm{g} / \mathrm{mL})$, 2,3-dihydrobilobetin (4) $(0.5-2 \mu \mathrm{g} / \mathrm{mL}), 4^{\prime}, 4^{\prime \prime \prime}$-O-dimethyl amentoflavone or isoginkgetin (5) $(1-2 \mu \mathrm{g} / \mathrm{mL})$, while $5,7,7^{\prime \prime}, 4^{\prime \prime \prime}$-tetra-O-methyl-hinokiflavone (3) and stigmasterol (1) presented moderate activity $(1.5-2 \mu \mathrm{g} / \mathrm{mL})$.

\section{Discussion}

Recently, the search for novel antibacterial agents has become a vital aim owing to the increasing levels of antibiotic resistance amongst pathogenic bacteria [22]. A promising trend in this aspect involves a focus on making use of medicinal plants that have many advantages including widely available resources, low or no side effects, low cost, in 
addition to having many antimicrobial properties [23]. To our knowledge, this is the first time the antibacterial activity of $C$. thouarsii extract against clinical isolates of $K$. pneumoniae has been investigated.

K. pneumoniae is an opportunistic pathogen that infects immunocompromised individuals causing a wide range of infections [24]. In the current work, C. thouarsii methanol extract exhibited antibacterial activity against $K$. pneumoniae clinical isolates with MIC values ranging from 4 to $32 \mu \mathrm{g} / \mathrm{mL}$.

For more comprehension of the impact of $C$. thouarsii extract on K. pneumoniae, a bacterial growth curve was constructed by plotting $\log \mathrm{OD}_{620}$ versus time before and after treatment. Suppression of the bacterial growth was found in $73.5 \%$ of the tested isolates. For clarification of how $C$. thouarsii extract was able to inhibit bacterial proliferation, the integrity of the cell membrane was tested. A significant increase $(p<0.05)$ in the release of nucleotides (DNA and RNA) from the cells was detected in $73.5 \%$ of the tested isolates which could be explained by induction of membrane disruption by $C$. thouarsii extract.

This was confirmed by testing the inner and outer membrane permeability. A significant increase in the inner and outer membrane permeability was detected after treatment with $C$. thouarsii extract in $67.6 \%$ and $58.8 \%$ of the isolates, respectively. Despite the impact of $C$. thouarsii extract on membrane properties, including the integrity and the inner and outer membrane permeability, it had a non-significant effect on membrane depolarization measured using flow cytometry. The bacterial membrane is a target for many antimicrobials, and some researchers have reported that certain plant extracts could influence membrane integrity [25] and membrane permeability [26].

To investigate the effect of $C$. thouarsii extract on bacterial morphology, we examined K. pneumoniae isolates using SEM before and after treatment. Some morphological changes were detected after treatment, indicating that the extract could completely collapse and lyse the bacterial cells. Latha et al. [27] reported morphological changes induced by certain plant extracts in Pseudomonas aeruginosa isolates.

Efflux pump-mediated resistance to antimicrobial agents has constricted the therapeutic options against many bacterial infections. Efflux pumps could reduce the concentration of antibiotics inside the bacterial cells, thus decreasing the antibiotic effect on bacteria [25]. Unfortunately, many bacterial isolates develop resistance to many antibiotics via an efflux pump system [28]. Therefore, we tested the effect of $C$. thouarsii extract on the efflux system in the tested K. pneumoniae isolates using fluorometric analysis of the efflux of $\mathrm{EtBr}$ (an efflux pump substrate) [29]. Noteworthy is the percentage of the isolates that showed fluorometric efflux of $\mathrm{EtBr}$, which decreased from $70.6 \%$ (24 out of 34 isolates) to $32.3 \%$ (11 out of 34 isolates) after treatment with $C$. thouarsii extract. This was further elucidated using qRT-PCR to detect the impact of $C$. thouarsii extract treatment on the expression of the genes encoding efflux pump. Our results showed that treatment with $C$. thouarsii extract decreased the expression of nor $\mathrm{E}, a c r \mathrm{~B}, m d f \mathrm{~A}$, and $y i h \mathrm{~V}$ efflux pump genes in $33.3 \%, 55.5 \%$, $55.5 \%$, and $44.4 \%$ of the selected K. pneumoniae isolates, respectively.

\section{Materials and Methods}

\subsection{Preparation of Plant Extract and Isolation of Pure Compounds}

Leaves from the Cycas thouarsii R.Br. family Cycadaceae were collected from El Abd Garden in Giza city on 14 January 2017. The identity of the plant was kindly confirmed by Esraa Ammar, Plant Ecology lecturer, Botany Department, Faculty of Science, Tanta University, and researcher, Rabea Sharawy, Agronomist and palm researcher. A voucher specimen (PGG-004) is kept at the Pharmacognosy Department, Faculty of Pharmacy, Tanta University.

The plant powdered material (1750 g) was extracted with methanol by percolation $(4 \times 5 \mathrm{~L})$. The extract was concentrated under reduced pressure to afford a residue $(208 \mathrm{~g})$. Total methanol residue (75 g) was resuspended in $\mathrm{MeOH}: \mathrm{H}_{2} \mathrm{O}(1: 1)$ then successively partitioned with $n$-hexane, dichloromethane, ethyl acetate, and finally $n$-butanol saturated with water to yield $18.28,23.74,3.82$, and $14.59 \mathrm{~g}$ residues, respectively. 
Dichloromethane fraction (10 g) of C. thouarsii was subjected to a silica gel column chromatography $(\phi 3.5 \times 80 \mathrm{~cm}, 200 \mathrm{~g}$ silica, fraction collected $50 \mathrm{~mL})$ using the gradient elution method, starting with $\mathrm{CH}_{2} \mathrm{Cl}_{2}$, and increasing the polarity using $\mathrm{MeOH}$ to afford four fractions (fr. A1-A4). Fr. A1 (557 mg, $\mathrm{CH}_{2} \mathrm{Cl}_{2}-\mathrm{MeOH} ; 96: 4$ eluate), Fr. A2 (1042 mg, $\mathrm{CH}_{2} \mathrm{Cl}_{2}-\mathrm{MeOH}$; 94:6 eluate), Fr. A3 (900 mg, $\mathrm{CH}_{2} \mathrm{Cl}_{2}-\mathrm{MeOH} ; 92: 8$ eluate), and Fr. A4 (617 mg, $\mathrm{CH}_{2} \mathrm{Cl}_{2}-\mathrm{MeOH}$; 84:16 eluate). Fr. A1 (557 mg, $\mathrm{CH}_{2} \mathrm{Cl}_{2}-\mathrm{MeOH}$; 96:4 eluate) was subjected to isocratic column chromatography using silica gel, eluted with $100 \%$ $\mathrm{CHCl}_{3}$. Subfractions (19-23) were collected and recrystallized with methanol to yield white crystals of compound 1 (13 mg). Fr. A2 (1042 mg, $\mathrm{CH}_{2} \mathrm{Cl}_{2}-\mathrm{MeOH}$; 94:6 eluate) was subjected to column chromatography on silica gel and eluted with $\mathrm{CHCl}_{3}$ and increasing polarity using $\mathrm{MeOH}$ to afford 6 fractions. Fr. 2 (231 mg) eluted with $\left(\mathrm{CHCl}_{3}-\mathrm{MeOH} ; 92: 8\right)$ was chromatographed on a silica gel column and eluted with $n$-hexane and increasing polarity using EtOAc (subfractions 8-12, n-hexane-EtOAc; 10:90) were collected to yield compound 2 (7 mg). Fr. 5 (300 mg) were subjected to isocratic column chromatography $\left(\mathrm{CH}_{2} \mathrm{Cl}_{2}\right.$ : MeOH; 99:1) to give yellow powder (53 mg) purified on Sephadex LH-20 eluted with $100 \% \mathrm{MeOH})$ to obtain compound 3 (9 mg). Fr. A3 (900 mg, $\mathrm{CH}_{2} \mathrm{Cl}_{2}-\mathrm{MeOH}$; $92: 8$ eluate) was subjected to column chromatography on silica gel and eluted with $\mathrm{CH}_{2} \mathrm{Cl}_{2}$ and increasing polarity using $\mathrm{MeOH}$ to give 5 subfractions. Subfraction 2 (82 $\mathrm{mg}$ ), eluted with $\left(\mathrm{CH}_{2} \mathrm{Cl}_{2}-\mathrm{MeOH} ; 90: 10\right)$, was purified on Sephadex $\mathrm{LH}-20$ eluted with $100 \% \mathrm{MeOH}$ to afford compound $4(10 \mathrm{mg})$. Subfraction 3 (397 mg), eluted with $\left(\mathrm{CH}_{2} \mathrm{Cl}_{2}-\mathrm{MeOH} ; 88: 12\right)$, was subjected to silica gel column chromatography eluted with $\mathrm{CHCl}_{3}-\mathrm{EtOAc}$ gradient elution to afford 3 fractions. Fraction 2 (100 mg), eluted with $\left(\mathrm{CHCl}_{3}-\mathrm{EtOAc} ; 90: 10\right)$, was further purified on Sephadex LH-20 eluted with $100 \% \mathrm{MeOH}$ to give compound 5 (12 mg). Fr. A4 (617 mg, $\mathrm{CH}_{2} \mathrm{Cl}_{2}-\mathrm{MeOH} ; 84: 16$ eluate) was subjected to silica gel column chromatography eluted with $\mathrm{CH}_{2} \mathrm{Cl}_{2}-\mathrm{MeOH}$; 90:10), then purified on Sephadex LH-20 eluted with 100\% $\mathrm{MeOH}$ to afford compound 6 (7 mg) (Scheme S1).

\subsection{Bacterial Isolates}

A total of $34 \mathrm{~K}$. pneumoniae isolates were collected from different departments of Tanta University Hospital. The clinical isolates were examined microscopically and were identified using standard biochemical tests according to MacFaddin [30]. Klebsiella pneumoniae (ATCC 13883) was utilized as a reference strain.

\subsection{Chemicals}

All chemicals used in the current study were purchased from Sigma-Aldrich (St. Louis, MO, USA), except DiBAC4(3) from Invitrogen (Waltham, MA, USA) and NPN from Himedia (Mumbai, India).

\subsection{Antibacterial Screening}

It was performed by the agar well diffusion method as previously described [31]. Briefly, $100 \mu \mathrm{L}\left(10^{6} \mathrm{CFU} / \mathrm{mL}\right)$ of bacterial suspension was spread on the surface of the Muller Hilton agar (MHA) plate using a swab. Then, 3 wells $6 \mathrm{~mm}$ in diameter were punched off using a sterile cork-borer, and each well was filled with $100 \mu \mathrm{L}(32 \mu \mathrm{g} / \mathrm{mL})$ of $C$. thouarsii extract using DMSO as a negative control and ciprofloxacin as a positive control. The plates were then incubated at $37^{\circ} \mathrm{C}$ for $24 \mathrm{~h}$.

\subsection{Determination of the MIC Values}

The broth microdilution method was utilized for the determination of the MIC value of C. thouarsii extract for each tested isolate in Muller-Hinton broth (MHB) (Oxoid, Basingstoke, UK) [32]. Equal volumes $(100 \mu \mathrm{L})$ of bacteria and serial twofold dilutions of C. thouarsii extract (from 32 to $500 \mu \mathrm{g} / \mathrm{mL}$ ) in MHB were mixed in the wells of a 96-well microtitration plate. Each plate had a positive control (untreated bacteria) and negative control (MHB only). After determination of the MICs of C. thouarsii extract for each isolate, 
all the following experiments were carried out before and after treatment of the tested isolates with a sub-inhibitory concentration $(0.5 \mathrm{MIC})$ of $C$. thouarsii extract.

\subsection{Bacterial Growth Curve}

The impact of $C$. thouarsii extract on the growth of K. pneumoniae isolates was examined using a spectrophotometric method [15]. In brief, bacterial cultures were incubated in a shaking incubator (New Brunswich, NJ, USA) at $37{ }^{\circ} \mathrm{C}$ for $24 \mathrm{~h}$ at $90 \mathrm{rpm}$. Then, a $4 \mathrm{~mL}$ suspension was taken from each flask at time intervals of $0,2,4,6,8$, and $24 \mathrm{~h}$. The OD values were determined at $620 \mathrm{~nm}$ with an $1800 \mathrm{UV} / \mathrm{Vis}$ spectrophotometer (SHIMADZU, Kyoto, Japan). Growth curves were formed through plotting log $\mathrm{OD}_{620}$ against the sampling time (h).

\subsection{Integrity of Cell Membranes}

The impact of $C$. thouarsii extract on cell membrane integrity of the tested isolates was inspected through monitoring the release of materials absorbing at $260 \mathrm{~nm}$ (A260) [16]. The tested isolates were grown in nutrient broth and the $\mathrm{OD}_{630}$ was adjusted to be 0.4 . Then, $1 \mathrm{~mL}$ of each bacterial suspension was centrifuged for $10 \mathrm{~min}$ at $11,000 \times g$, and the pellet was resuspended in a solution of $0.5 \% \mathrm{NaCl}$. The final suspension was adjusted to an absorbance of 0.7 at $420 \mathrm{~nm}$. The release of materials absorbing at $260 \mathrm{~nm}$ from bacterial cells was tracked over time utilizing an $1800 \mathrm{UV} /$ Vis spectrophotometer (SHIMADZU, Kyoto, Japan).

\subsection{Inner Membrane Permeability Assay}

It was investigated by measuring the release of the $\beta$-galactosidase enzyme from the cytoplasm of the tested isolates using ONPG as an enzyme substrate [17]. An overnight bacterial suspension grown in nutrient broth and supplemented with $2 \%$ lactose was centrifuged, and the pellet was washed and resuspended in a solution of $0.5 \% \mathrm{NaCl}$. Then, $150 \mu \mathrm{L}$ of $34 \mathrm{mM}$ ONPG solution was added to $1.6 \mathrm{~mL}$ of the bacterial suspension. The produced ONP was detected over time via monitoring the increase in the absorbance at 420 using an ELISA reader (Sunrise Tecan, Männedorf, Switzerland).

\subsection{Outer Membrane Permeability Assay}

It was determined according to the method previously described [18,33]. In brief, a stock solution of $5 \mathrm{mM} \mathrm{NPN}$ in ethanol was diluted using potassium phosphate buffer (PBS) ( $\mathrm{pH}$ 7.5) to reach a concentration of $20 \mu \mathrm{M}$. The fluorescence of the samples was measured using a fluorescence spectrophotometer (SHIMADZU, Kyoto, Japan) at an excitation and emission wavelength of 340 and $420 \mathrm{~nm}$, respectively.

\subsection{Membrane Depolarization Assay}

The tested isolates were harvested by centrifugation and resuspended in PBS; then, they were stained using $5 \mu \mathrm{g} / \mathrm{mL} \mathrm{DiBAC}_{4}(3)$ (Molecular Probe). The cell staining was analyzed using an FACS verse flow cytometer (BD Biosciences, New York, NY, USA) [17,19].

\subsection{SEM Examination}

The tested isolates were examined using an electron microscope as previously described [20] in the electron microscope unit, Tanta University, Egypt, using SEM (Jeol-1200 ECII) (Akashi Seisakusho, Japan).

\subsection{Evaluation of Efflux Activity Using Cartwheel Method}

Efflux of EtBr was examined using the cartwheel method [21]. Tryptic soy agar plates containing EtBr with concentrations ranging from 0 to $2.5 \mathrm{mg} / \mathrm{L}$ were set-up and well protected from light. The plates were then divided into sectors and the tested bacterial suspensions were swabbed onto the plates starting from the center toward the edges, using the reference strain as a negative control, and then incubated overnight at $37^{\circ} \mathrm{C}$. The 
plates were inspected using an $1800 \mathrm{UV}$-Vis transilluminator (SHIMADZU, Kyoto, Japan), and the lowest concentration of EtBr that produced fluorescence of the bacterial isolates was determined.

\subsection{3. $q R T-P C R$}

qRT-PCR was utilized to determine the relative expression of the efflux pump genes (nor $\mathrm{E}, a c r \mathrm{~B}, m d f \mathrm{~A}$, and $y i h \mathrm{~V})$ using gap $\mathrm{A}$ as a housekeeping gene [34]. All the measurements were carried out in triplicate, and they were expressed as mean $\pm \mathrm{SD}$ values. Total RNA was extracted by the Purelink ${ }^{\circledR}$ RNA Mini Kit (Thermo SCIENTIFIC, Waltham, MA, USA), and $1 \mu \mathrm{L}$ of RNA was used for the synthesis of cDNA by the power first-strand cDNA kit (iNtRON Biotechnology, Seongnam, Korea). The sequences of primers used in the amplification of the tested genes are shown in (Supplementary Materials, Table S1). The amplification was performed by a Rotor-Gene Q5 plex instrument (Qiagen, Hilden, Germany) using a Power SYBR ${ }^{\circledR}$ Green master mix (Thermo SCIENTIFIC, Waltham, MA, USA). The threshold cycle method $\left(2^{-\Delta \Delta C T}\right)$ was utilized [35] to analyze the changes in gene expression in each sample relative to the control (bacterial isolates before treatment with plant extract and its expression was set to 1 ).

\subsection{General Instruments}

A JEOL ECA-500 II NMR spectrometer was used to record NMR spectra at $500 \mathrm{MHz}$ for ${ }^{1} \mathrm{H}$ and $125 \mathrm{MHz}$ for ${ }^{13} \mathrm{C}$. DMSO- $d_{6}$ or $\mathrm{CDCl}_{3}$ were used to dissolve NMR samples. Chemical shifts $\delta$ were standardized to the solvent resonances. A Thermo Scientific ISQ Quantum Access MAX Triple Quadrupole system, Xcalibur 2.1 software, and USA Mass Spectrometer were used. Jasco's FT/IR-6100 spectrophotometer was used to record IR spectra on $\mathrm{KBr}$ discs. The "Galen Kamp-type" melting point apparatus was used. Polarimeter models from Rudolph Research Analytical, USA, were used to detect optical rotation. Material for column chromatography: silica gel (Merck, 70-230 mesh), Sephadex LH-20 (Sigma-Aldrich Chemical Co. St. Louis, MO, USA), ODS (RPC18, Merck, Germany), silica gel $\mathrm{F}_{254}$ (Merck, 70-230 mesh). Camag UV lamps at 254 and $366 \mathrm{~nm}$ were used to observe the results. For spot detection, $\mathrm{AlCl}_{3}$ or $10 \%$ sulfuric acid spray reagents were used independently.

\subsection{Statistical Analysis}

The one-way analysis of variance test (ANOVA) was used to analyze the results via SPSS software. The results with $p$ significance values of $<0.05$ were regarded as statistically significant.

\section{Conclusions}

K. pneumoniae pathogenic bacteria can cause many infections in addition to its multidrug resistance making its treatment more difficult. To overcome this problem, research on the anti-pathogenic and anti-infective effects of different plant extracts is increasing. In our study, C. thouarsii extract had antibacterial activity against K. pneumoniae clinical isolates. In addition, it inhibited bacterial growth and significantly decreased the membrane integrity of the bacterial cells. It also significantly decreased the inner and outer membrane permeability. Based on the scanning electron microscopy images, the extract had a drastic effect on the morphology of K. pneumoniae cells. The efflux inhibitory effect of C. thouarsii extract was investigated using the EtBr cartwheel method, and it was confirmed by examination of its influence on the expression of the genes encoding efflux pumps using qRT-PCR. A significant decrease in the expression of the efflux pump genes was detected in the selected isolates with percentages ranging from $33.3 \%$ to $55.5 \%$. Further studies are highly needed soon to check the pharmacokinetic and pharmacodynamics properties of $C$. thouarsii extract to make use of its clinical value. One new biflavonoid $5,7,7^{\prime \prime}, 4^{\prime \prime \prime}$-tetra-O-methyl-hinokiflavone (3) was isolated from $C$. thouarsii leaves, in addition to five known compounds for the first time (stigmasterol, naringenin, 2,3-dihydrobilobetin, 
$4^{\prime}, 4^{\prime \prime \prime}$-O-dimethyl amentoflavone or isoginkgetin, hinokiflavone). The MICs of the isolated compounds ranged from 0.25 to $2 \mu \mathrm{g} / \mathrm{mL}$. Thus, $C$. thouarsii could be a promising source for new antimicrobials.

Supplementary Materials: The following are available online at https://www.mdpi.com/article/ 10.3390/ph14080756/s1, Figure S1: IR spectrum of compound 3; Figure S2: ${ }^{1} \mathrm{H}-\mathrm{NMR}$ spectrum of compound 3; Figure S3: ${ }^{13} \mathrm{C}-\mathrm{NMR}$ spectrum of compound 3; Figure S4: HMBC spectrum of compound 3; Figure S5: COSY spectrum of compound 3; Figure S6: ESI mass spectrum of compound 3; Scheme S1: Column chromatography of methylene chloride fraction of $C$. thouarsii leaves.

Author Contributions: Conceptualization, M.E.-A. and A.A.K.; Investigation, W.A.N. and E.E.; Methodology, W.A.N. and E.E.; Supervision, M.E.-A. and A.A.K.; Writing-original draft, W.A.N. and E.E.; Writing-review and editing, M.E.-A. and A.A.K. All authors have read and agreed to the published version of the manuscript.

Funding: This research received no external funding.

Institutional Review Board Statement: Not applicable.

Informed Consent Statement: Not applicable.

Data Availability Statement: The authors confirm that the data supporting this study are available within the article and its supplementary materials.

Acknowledgments: The authors would like to express their gratitude to Rabea Sharawy, for providing the necessary plant for this study, and Esraa Ammar, Plant Ecology lecturer, Botany Department, Faculty of Science, Tanta University, for the identification of the plant.

Conflicts of Interest: The authors declare no conflict of interest.

\section{References}

1. Effah, C.Y.; Sun, T.; Liu, S.; Wu, Y. Klebsiella pneumoniae: An increasing threat to public health. Ann. Clin. Microbiol. Antimicrob. 2020, 19, 1-9. [CrossRef]

2. Benthall, G.; Touzel, R.E.; Hind, C.K.; Titball, R.W.; Sutton, J.M.; Thomas, R.J.; Wand, M.E. Evaluation of antibiotic efficacy against infections caused by planktonic or biofilm cultures of Pseudomonas aeruginosa and Klebsiella pneumoniae in Galleria mellonella. Int. J. Antimicrob. Agents 2015, 46, 538-545. [CrossRef]

3. Ni, R.T.; Onishi, M.; Mizusawa, M.; Kitagawa, R.; Kishino, T.; Matsubara, F.; Tsuchiya, T.; Kuroda, T.; Ogawa, W. The role of RND-type efflux pumps in multidrug-resistant mutants of Klebsiella pneumoniae. Sci. Rep. 2020, 10, 1-10. [CrossRef]

4. Carvalho, I.; Chenouf, N.S.; Carvalho, J.A.; Castro, A.P.; Silva, V.; Capita, R.; Alonso-Calleja, C.; Enes Dapkevicius, M.d.L.N.; Igrejas, G.; Torres, C. Multidrug-resistant Klebsiella pneumoniae harboring extended spectrum $\beta$-lactamase encoding genes isolated from human septicemias. PLoS ONE 2021, 16, e0250525. [CrossRef]

5. Giske, C.G.; Monnet, D.L.; Cars, O.; Carmeli, Y. Clinical and economic impact of common multidrug-resistant gram-negative bacilli. Antimicrob. Agents Chemother. 2008, 52, 813-821. [CrossRef]

6. Cousins, S.; Witkowski, E. African cycad ecology, ethnobotany and conservation: A synthesis. Bot. Rev. 2017, 83, 152-194. [CrossRef]

7. Negm, W.; Abo El-Seoud, K.; Kabbash, A.; El-Aasr, M. Investigation of the Biological Activity Some Gymnosperm Plants Belong to Cycadales Order. J. Adv. Med. Pharm. Res. 2020, 1, 9-13. [CrossRef]

8. Negm, W.A.; Abo El-Seoud, K.A.; Kabbash, A.; Kassab, A.A.; El-Aasr, M. Hepatoprotective, cytotoxic, antimicrobial and antioxidant activities of Dioon spinulosum leaves Dyer Ex Eichler and its isolated secondary metabolites. Nat. Prod. Res. 2020, 1-11. [CrossRef]

9. Negm, W.A.; Ibrahim, A.E.-R.S.; El-Seoud, K.A.; Attia, G.I.; Ragab, A.E. A new cytotoxic and antioxidant Amentoflavone Monoglucoside from Cycas revoluta Thunb growing in Egypt. J. Pharm. Sci. Res. 2016, 8, 343.

10. Moawad, A.; Hetta, M.; Zjawiony, J.K.; Jacob, M.R.; Hifnawy, M.; Ferreira, D. Phytochemical investigation of Cycas circinalis and Cycas revoluta leaflets: Moderately active antibacterial biflavonoids. Planta Med. 2010, 76, 796. [CrossRef] [PubMed]

11. Dora, G.; Edwards, J. Taxonomic status of Lanaria lanata and isolation of a novel biflavone. J. Nat. Prod. 1991, 54, 796-801. [CrossRef]

12. Markham, K.R.; Sheppard, C.; Geiger, H. 13C NMR studies of some naturally occurring amentoflavone and hinokiflavone biflavonoids. Phytochemistry 1987, 26, 3335-3337. [CrossRef]

13. Geiger, H.; Seeger, T.; Hahn, H.; Zinsmeister, H.D.; Markham, K.R.; Wong, H. 1HNMR Assignments in Biflavonoid Spectra by Proton-Detected CH Correlation. Z. Nat. C 1993, 48, 821-826.

14. Meurer-Grimes, B.; Yu, J. Chamaecyparin-a rare biflavone from Selaginella species. Z. Nat. C 1999, 54, 1143-1144. [CrossRef] 
15. El-Banna, T.; Abd El-Aziz, A.; Sonbol, F.; El-Ekhnawy, E. Adaptation of Pseudomonas aeruginosa clinical isolates to benzalkonium chloride retards its growth and enhances biofilm production. Mol. Biol. Rep. 2019, 46, 3437-3443. [CrossRef]

16. Liu, H.; Du, Y.; Wang, X.; Sun, L. Chitosan kills bacteria through cell membrane damage. Int. J. Food Microbiol. 2004, 95, 147-155. [CrossRef]

17. Seong, M.; Lee, D.G. Silver nanoparticles against Salmonella enterica serotype typhimurium: Role of inner membrane dysfunction. Curr. Microbiol. 2017, 74, 661-670. [CrossRef]

18. Halder, S.; Yadav, K.K.; Sarkar, R.; Mukherjee, S.; Saha, P.; Haldar, S.; Karmakar, S.; Sen, T. Alteration of Zeta potential and membrane permeability in bacteria: A study with cationic agents. SpringerPlus 2015, 4, 1-14. [CrossRef] [PubMed]

19. Sonbol, F.I.; El-Banna, T.; Abd El-Aziz, A.A.; El-Ekhnawy, E. Impact of triclosan adaptation on membrane properties, efflux and antimicrobial resistance of Escherichia coli clinical isolates. J. Appl. Microbiol. 2019, 126, 730-739. [CrossRef]

20. McDowell, E.; Trump, B. Histologic fixatives suitable for diagnostic light and electron microscopy. Arch. Pathol. Lab. Med. 1976, 100, 405-414. [PubMed]

21. Abdelaziz, A.; Sonbol, F.; Elbanna, T.; El-Ekhnawy, E. Exposure to sublethal concentrations of benzalkonium chloride induces antimicrobial resistance and cellular changes in Klebsiellae pneumoniae clinical isolates. Microb. Drug Resist. 2019, 25, 631-638. [CrossRef] [PubMed]

22. Aslam, B.; Wang, W.; Arshad, M.I.; Khurshid, M.; Muzammil, S.; Rasool, M.H.; Nisar, M.A.; Alvi, R.F.; Aslam, M.A.; Qamar, M.U. Antibiotic resistance: A rundown of a global crisis. Infect. Drug Resist. 2018, 11, 1645. [CrossRef]

23. Anand, U.; Jacobo-Herrera, N.; Altemimi, A.; Lakhssassi, N. A comprehensive review on medicinal plants as antimicrobial therapeutics: Potential avenues of biocompatible drug discovery. Metabolites 2019, 9, 258. [CrossRef] [PubMed]

24. Lee, C.-R.; Lee, J.H.; Park, K.S.; Jeon, J.H.; Kim, Y.B.; Cha, C.-J.; Jeong, B.C.; Lee, S.H. Antimicrobial resistance of hypervirulent Klebsiella pneumoniae: Epidemiology, hypervirulence-associated determinants, and resistance mechanisms. Front. Cell. Infect. Microbiol. 2017, 7, 483. [CrossRef]

25. Chitemerere, T.A.; Mukanganyama, S. Evaluation of cell membrane integrity as a potential antimicrobial target for plant products. BMC Complementary Altern. Med. 2014, 14, 1-8. [CrossRef] [PubMed]

26. Górniak, I.; Bartoszewski, R.; Króliczewski, J. Comprehensive review of antimicrobial activities of plant flavonoids. Phytochem. Rev. 2019, 18, 241-272. [CrossRef]

27. Latha, L.Y.; Darah, I.; Kassim, M.J.N.M.; Sasidharan, S. Antibacterial activity and morphological changes of Pseudomonas aeruginosa cells after exposure to Vernonia cinerea extract. Ultrastruct. Pathol. 2010, 34, 219-225. [CrossRef]

28. Sharma, A.; Gupta, V.K.; Pathania, R. Efflux pump inhibitors for bacterial pathogens: From bench to bedside. Indian J. Med. Res. 2019, 149, 129.

29. Yazdankhah, S.P.; Scheie, A.A.; Høiby, E.A.; Lunestad, B.-T.; Heir, E.; Fotland, T.Ø.; Naterstad, K.; Kruse, H. Triclosan and antimicrobial resistance in bacteria: An overview. Microb. Drug Resist. 2006, 12, 83-90. [CrossRef]

30. MacFaddin, J. Biochemical Tests for Identification of Medical Bacteria; Williams and Wilkins: Philadelphia, PA, USA, $2000 ;$ p. 113.

31. Das, D.C.; De, S.; Bhattacharya, S.; Das, M. Antibacterial activity and Phytochemical analysis of Cardanthera difformis Druce leaf extracts from West Bengal, India. Int. J. Phytomed. 2013, 5, 446.

32. Wayne, A. Performance Standards for Antimicrobial Susceptibility Testing; 20th Informational Supplement; CLSI Document; Clinical and Laboratory Standards Institute (CLSI): Howard County, MA, USA, 2017.

33. Attallah, N.G.; Negm, W.A.; Elekhnawy, E.; Altwaijry, N.; Elmongy, E.I.; El-Masry, T.A.; Alturki, E.A.; Yousef, D.A.; Y Shoukheba, M. Antibacterial Activity of Boswellia sacra Flueck. Oleoresin Extract against Porphyromonas gingivalis Periodontal Pathogen. Antibiotics 2021, 10, 859. [CrossRef]

34. Huguet, A.; Pensec, J.; Soumet, C. Resistance in Escherichia coli: Variable contribution of efflux pumps with respect to different fluoroquinolones. J. Appl. Microbiol. 2013, 114, 1294-1299. [CrossRef]

35. Livak, K.J.; Schmittgen, T.D. Analysis of relative gene expression data using real-time quantitative PCR and the $2^{-\Delta \Delta C T}$ method. Methods 2001, 25, 402-408. [CrossRef] [PubMed] 